RASĀYAN J. Chem.

Vol. 13 | No. 1 |282 - 290| January - March | 2020 ISSN: 0974-1496 | e-ISSN: 0976-0083 | CODEN: RJCABP

RJC http://www.rasayanjournal.com http://www.rasayanjournal.co.in

\title{
SYNTHESIS OF NEW SULPHANILAMIDE BASED SCHIFF BASE NICKEL COMPLEXES WITH STUDY OF ITS ANTIBACTERIAL ACTIVITY AND NANOPARTICLE SYNTHESIS
}

\author{
R. R. Surve ${ }^{1, *}$ and S. T. Sankpal ${ }^{2}$ \\ ${ }^{1}$ Department of Chemistry, A.C.S. College, Lanja- 416701 (Maharashtra), India. \\ ${ }^{2}$ A.S.P. College, Devrukh-415804, Dist. Ratnagiri, Maharashtra, India. \\ *E-mail: surverishikesh1@gmail.com
}

\begin{abstract}
Schiff base contains the Azomethine group prepared by reaction of the carbonyl group and amine group. In this project, Schiff bases of sulphanilamide on the treatment of imidazole-2-carboxaldehyde and Dehydroacetic acid have been synthesized. Further, their Nickel complexes have been synthesized. They were characterized by IR, Mass, NMR, UV-Vis spectra and found to have square planar geometry. They were screened with few bacteria and found to have good antibacterial activity against gram-negative bacteria. Further, NiO nanoparticles were synthesized by thermal decomposition of the above synthesized Nickel Schiff base complexes and found to have 93$98 \mathrm{~nm}$ particle size.
\end{abstract}

Keywords: Sulphanilamide, Schiff Base, Square Planar, Antibacterial Activity, Nanoparticles.

(C) RASĀYAN. All rights reserved

\section{INTRODUCTION}

Schiff base simply contains Azomethine functional group and is synthesized by condensation of the carbonyl group with the amine. ${ }^{1}$ This Schiff base has a unique property to bind with different metal ions increasing its applicability in the different fields. This Schiff bases have huge applications in most of the field especially in the pharmaceutics as shown below in the Fig.-1 and even for the quantitative analysis, hence increasing attention of many researchers to derive more new Schiff base metal complexes. ${ }^{2,3}$

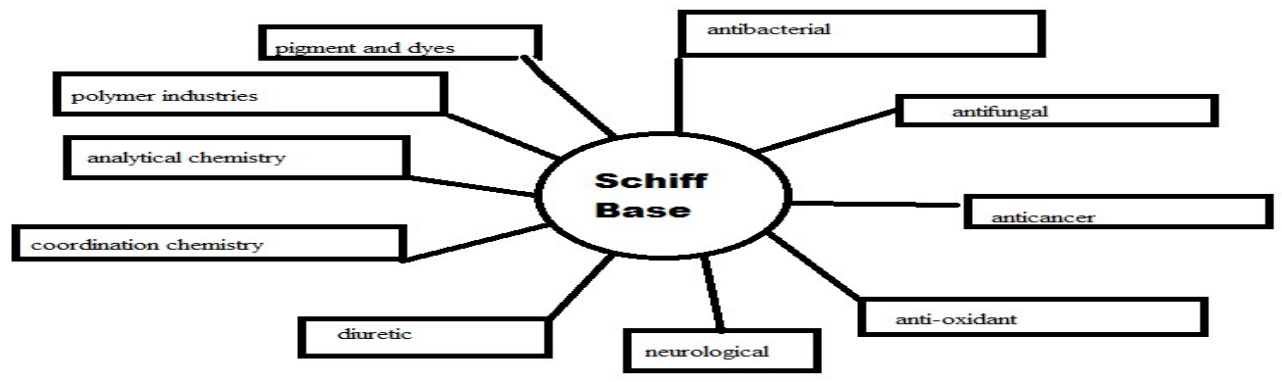

Fig.-1: Applications of Schiff Bases

In the Present Study, we focus on the synthesis of Schiff base by combining sulphanilamide with two different aldehydes and study of its antimicrobial activity. It is an organic compound consists of an aniline derivative with the presence of sulphonamide group. Modern antibiotics have displaced sulphanilamide with some more efficient potent antibiotics. The Sulphanilamide based Schiff base metal complexes are of capable research interest owing to the prevalent antibacterial resistance in the pharmacy field. The Rasayan J. Chem., 13(1), 282-290(2020) http://dx.doi.org/10.31788/RJC.2020.1315532

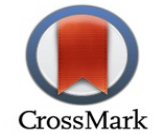


RASĀYAN J. Chem.

Vol. 13 | No. 1 | 282 - 290| January - March | 2020

stoichiometry of the formed Schiff base metal complex can be determined by slope ratio method, mole ratio method and jobs method of continuous variation. ${ }^{4}$

\section{EXPERIMENTAL}

Schiff base compounds were prepared by following the published standard procedures. ${ }^{5}$ all the chemicals were obtained from Merck.

\section{Synthesis of Schiff Base I}

$(E)-4-(1 H$-imidazol-2-yl)methyleneamino)benzenesulfonamide

The above following Schiff bases are synthesized by reflux of mixture of aldehyde and aromatic amine in water. 1 milimole of each imidazole-2-carboxaldehyde and sulphanilamide in $10 \mathrm{~cm}^{3}$ distilled water was taken in the round bottom flask. This was refluxed for 3 hours. After completion of the reflux process, the content was cooled in air. The Schiff base was collected in solid-state, washed, recrystallized through ethanol and dried in a desiccator. The formed ligand is stable at room temperature. It is soluble in alcohol, chloroform at high temperature, DMSO and DMF.

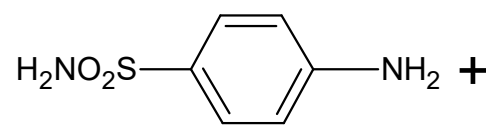<smiles>O=Cc1ncc(CCCCCCCCS(=O)(=O)c2ccc(N=Cc3ncc[nH]3)cc2)[nH]1</smiles>

Scheme-1: Synthesis of Schiff Base $\mathrm{L}_{1}$

\section{Synthesis of Metal Complex}

The metal complex is produced by reflux of the ethanol solution of above-prepared ligand and Nickel chloride in 2:1 mole ratio, i.e. 2 millimoles of the above-prepared ligand in slight excess was taken in a round bottom flask with 25 ethanol. The Schiff base gets dissolved in it. 1 millimole of Nickel chloride was taken and dissolved in $5 \mathrm{~cm}^{3}$ of alcohol. This dissolved Nickel chloride was further added drop-wise in hot ligand solution. Few drops of dilute ammonia are added to maintaining its $\mathrm{pH}$ in the range of 7.5 to 8.0. The contents were refluxed for three hours. The precipitate of complex formed was filtered and washed with dilute ammonia and dried in a desiccator.

\section{Synthesis of Schiff Base II}

(E)-4-(1-(4-methyl-2,6-dioxocyclohex-3-enyl)ethylideneamino)benzenesulfonamide

Schiff base II is synthesized by reflux of mixture of DHA and sulphanilamide in alcohol. 1milimole of both DHA and sulphanilamide was taken in $10 \mathrm{~cm}^{3}$ ethanol in the round bottom flask. It was refluxed for 3 hours. After refluxing, the content is cooled. The Schiff bases were collected in solid-state, washed, recrystallized through ethanol, and dried in a desiccator. This ligand is also stable at room temperature. It is soluble in alcohol, chloroform at high temperature, DMSO and DMF.

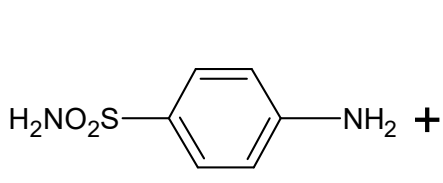

\section{Synthesis of Metal Complex}

The metal complex is produced by reflux of the ethanol solution of above-prepared ligand and Nickel chloride in a 2:1 ratio, i.e. 2 millimoles of the above-prepared ligand in slight excess was taken in a round bottom flask with $10 \mathrm{ml}$ ethanol. 1 millimole of Nickel chloride was taken and dissolved in $10 \mathrm{~cm}^{3}$ alcohol. This dissolved Nickel chloride solution was added drop-wise in hot ligand solution. Few drops of 
RASĀYAN J. Chem.

Vol. 13 | No. 1 | 282 - 290| January - March | 2020

dilute ammonia are added to maintain its $\mathrm{pH}$ in the range of 7.5 to 8.0 . These were refluxed basically for 2 hours. The precipitate of complex formed was filtered and washed with dilute ammonia and desiccated.

RESULTS AND DISCUSSION

The Physical Properties of above Synthesised Schiff Bases are given in the following table and discussed in coming sections.

Table-1: Physical Properties of Schiff Bases

\begin{tabular}{c|c|c|c|c|c|c|c|c|c}
\hline S. No. & $\begin{array}{c}\text { Molecular } \\
\text { Formula }\end{array}$ & $\begin{array}{c}\text { Compound } \\
\text { Code }\end{array}$ & $\begin{array}{c}\text { Melting } \\
\text { Point }\end{array}$ & Colour & \multicolumn{5}{|c}{ Analytical Data } \\
\cline { 5 - 10 } & & & $\mathrm{C}$ & $\mathrm{H}$ & $\mathrm{N}$ & $\mathrm{O}$ & $\mathrm{S}$ \\
\hline 1. & $\mathrm{C}_{10} \mathrm{H}_{13} \mathrm{~N}_{4} \mathrm{O}_{2} \mathrm{~S}$ & $\mathrm{~L}_{1}$ & $>300^{0} \mathrm{C}$ & Yellow & 48 & 5.2 & 22.4 & 12.8 & 12.8 \\
\hline 2. & $\mathrm{C}_{15} \mathrm{H}_{16} \mathrm{~N}_{2} \mathrm{O}_{4} \mathrm{~S}$ & $\mathrm{~L}_{2}$ & $>300^{0} \mathrm{C}$ & $\begin{array}{c}\text { Pale } \\
\text { yellow }\end{array}$ & 55.7 & 4.9 & 8.6 & 19.81 & 9.9 \\
\hline
\end{tabular}

\section{Spectral Analysis of Schiff Base L}

\section{Infra-Red Spectral Data}

The data of IR spectra of the above synthesized Schiff base ligand shows $-\mathrm{C}=\mathrm{N}$ - stretching band around $1800 \mathrm{~cm}^{-1}$ and also one of the band at 1744.10 which can be consigned to the azomethine moiety, this confirms the condensation between the amino group of sulphanilamide and the ketone of DHA information of the Schiff base. ${ }^{6,7}$

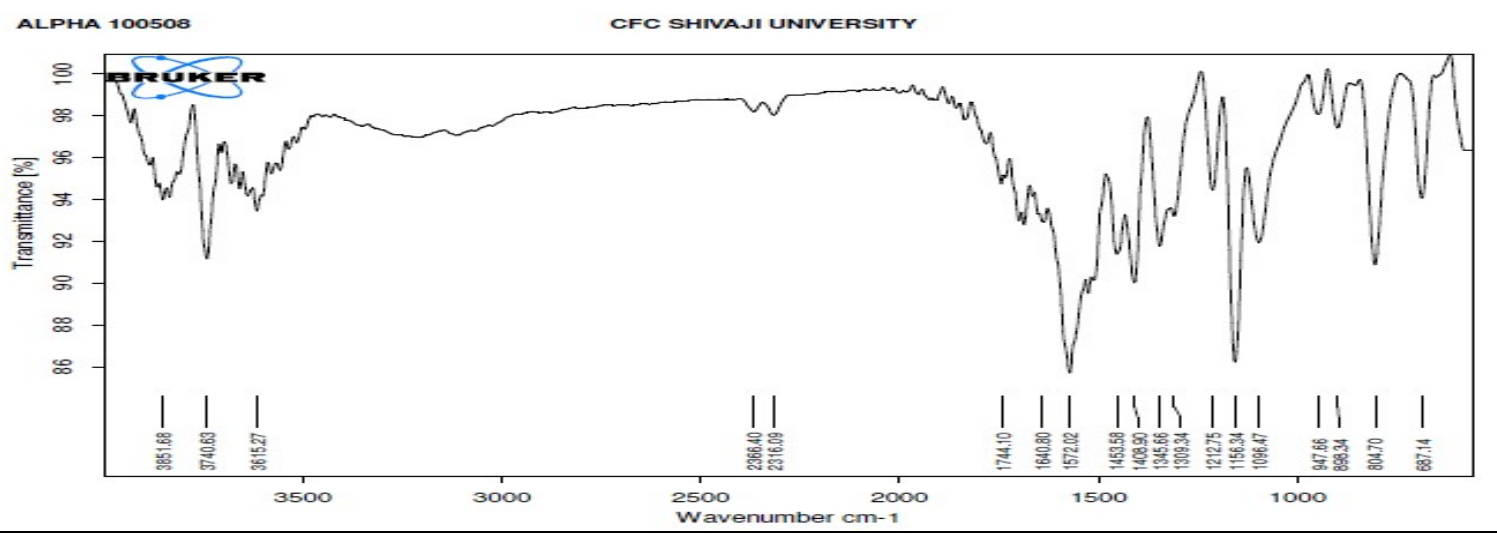

Fig.-2: IR Spectra of Schiff Base $\mathrm{L}_{1}$

\section{Mass Spectra}

The Mass spectra revealed that molecular ion peak at $\mathrm{m} / \mathrm{e} 249.12$ indicates the formation of the Schiff base ligand which further undergoes fragmentations giving other smaller peaks.

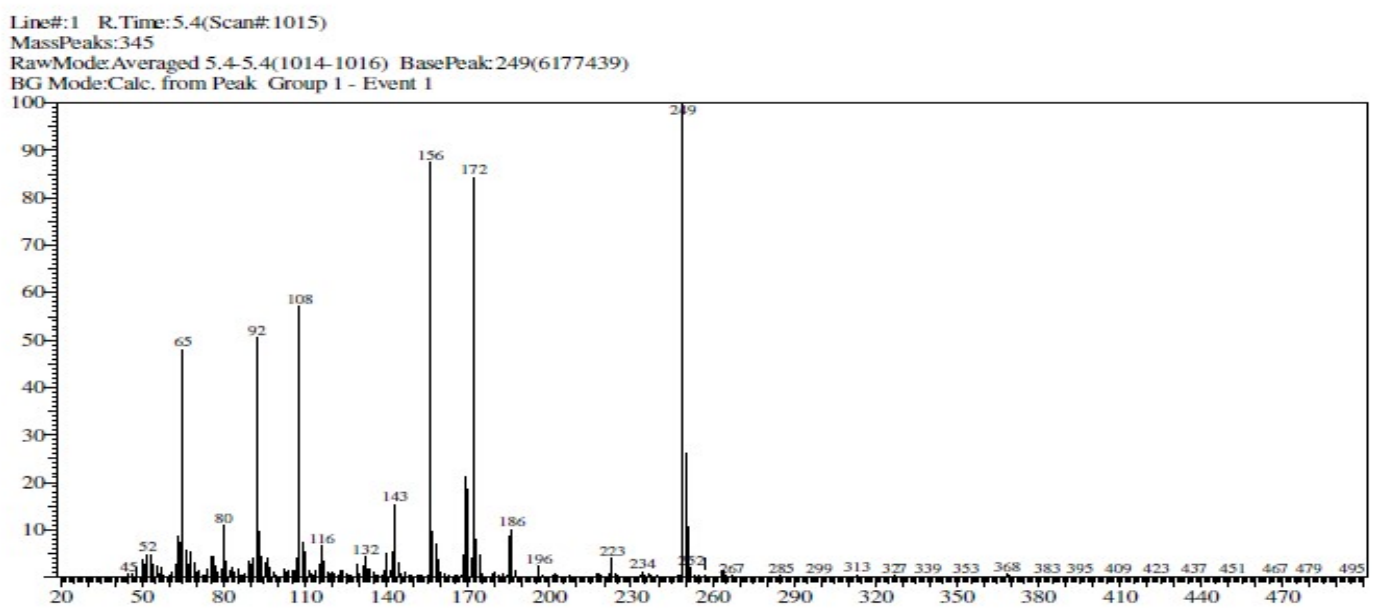

Fig.-3: Mass Spectra of Schiff Base $\mathrm{L}_{1}$ 
RASĀYAN J. Chem.

Vol. 13 | No. 1 | 282 - 290| January - March | 2020

\section{NMR Spectra}

$\mathrm{H}^{1} \mathrm{NMR}$ studies show the peak that $\delta 2.0 \mathrm{ppm}$ of $-\mathrm{NH}_{2}$ group attached to $-\mathrm{SO}_{2}$ group. The peak from $\delta$ 6.71 to 7.71 multiplet is present for the Benzene ring. The peak at $3.3 \mathrm{ppm} \delta$ is for $-\mathrm{N}=\mathrm{CH}-$, methine group. $2.0 \mathrm{ppm} \delta$ for $\mathrm{N}-\mathrm{H}$ group, 2.6 and 2.65 triplets for $>\mathrm{CH}_{2}$ group of imidazole. The peak for one more $-\mathrm{NH}_{2}$ group at around $3.5 \mathrm{ppm}$ is not obtained indicating desired product formation. ${ }^{8}$

\section{Spectral Studies of Schiff Base $\mathbf{L}_{2}$ \\ Infra-Red Spectral Data}

IR spectra of the above synthesized Schiff base $\mathrm{L}_{2}$ shows the IR band around $1685.69 \mathrm{~cm}^{-1}$ which can be assigned to the azomethine moiety, this confirms the condensation between the amino group of sulphanilamide and the ketone of DHA information of the Schiff base.

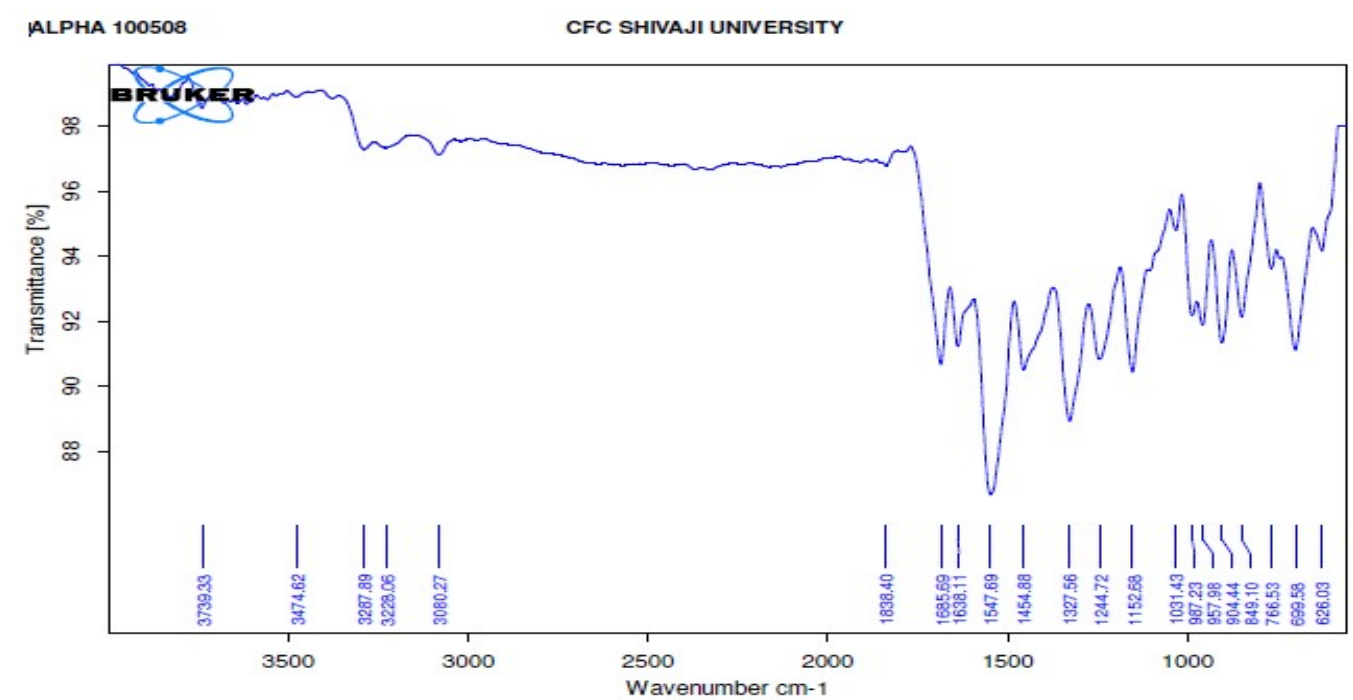

Fig.-4: IR Spectra of Schiff Base $\mathrm{L}_{2}$

\section{Mass Spectra}

The Mass spectra revealed that molecular ion peak at $\mathrm{m} / \mathrm{e} 323.3$ indicates formation of the Schiff base ligand which further undergoes fragmentations giving other smaller peaks.

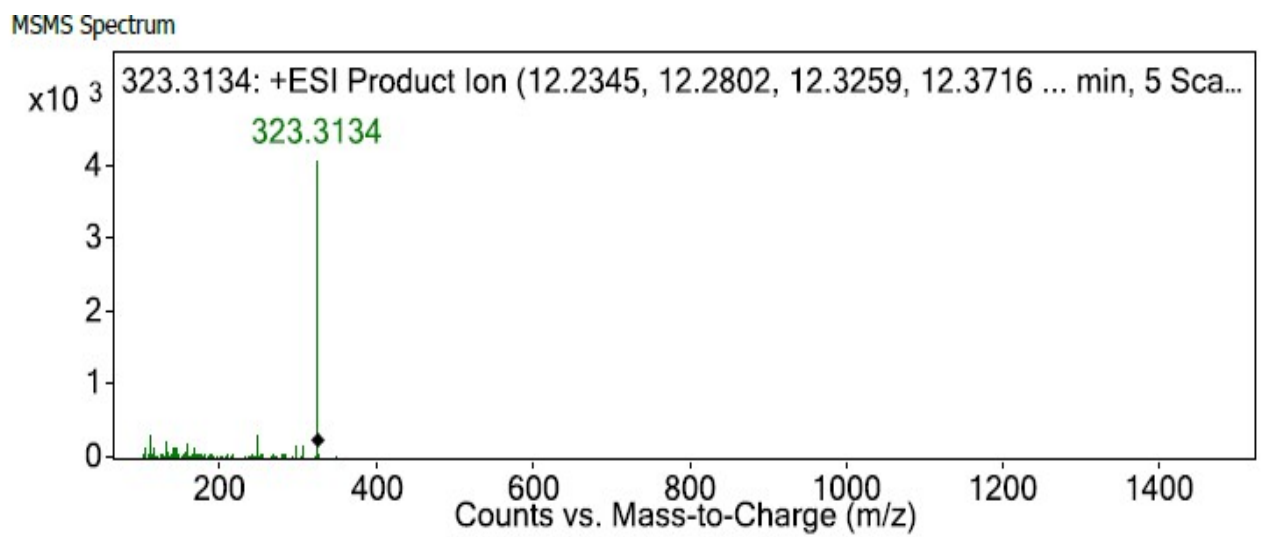

\section{NMR Spectra}

Fig.-5: Mass Spectra of Schiff Base $\mathrm{L}_{2}$

$\mathrm{H}^{1} \mathrm{NMR}$ studies show the peak that $\delta 0.9 \mathrm{ppm}$ singlet and $\delta 1.71 \mathrm{ppm}$ singlet of the methyl group of DHA. $\delta 2.0 \mathrm{ppm}$ of $-\mathrm{NH}_{2}$ group attached to $-\mathrm{SO}_{2}$ group. $3.2 \mathrm{ppm} \delta$ singlet for the methane group. 3.17 and 3.02 $\mathrm{ppm}$ for the methylene group. Peak around 7.5 to $7.9 \mathrm{ppm}$ multiplet indicates benzene. The peak for the para-substituted $-\mathrm{NH}_{2}$ group is not found indicated undergoing condensation reaction. 
RASĀYAN J. Chem.

Vol. 13 | No. 1 | 282 - 290| January - March | 2020

\section{Physical Properties of Above Synthesised Schiff Bases Metal Complexes}

Table-2: Physical Properties of Schiff Bases Metal Complexes

\begin{tabular}{|c|c|c|c|c|c|c|c|c|c|c|}
\hline \multirow{2}{*}{ S. No. } & \multirow{2}{*}{$\begin{array}{l}\text { Molecular } \\
\text { Formula }\end{array}$} & \multirow{2}{*}{$\begin{array}{l}\text { Compound } \\
\text { Code }\end{array}$} & \multirow[t]{2}{*}{ Colour } & \multirow{2}{*}{$\begin{array}{c}{ }_{\mathrm{p}} \mathrm{H} \text { Range } \\
\text { of } \\
\text { Precipitati } \\
\text { on }\end{array}$} & \multirow{2}{*}{$\begin{array}{l}\text { M.P/ D.P. } \\
\text { Temperatu } \\
\text { re }\end{array}$} & \multicolumn{5}{|c|}{ Analytical Data (\%) } \\
\hline & & & & & & $\mathrm{C}$ & $\mathrm{H}$ & $\mathrm{N}$ & $\mathrm{O}$ & $\mathrm{Ni}$ \\
\hline 1 & $\begin{array}{c}\mathrm{NiC}_{10} \mathrm{H}_{13} \mathrm{~N}_{4} \mathrm{O}_{2} \\
\mathrm{~S}\end{array}$ & $\mathrm{Ni}-\mathrm{L}_{1}$ & Green & $7.5-8.0$ & $>300^{\circ} \mathrm{C}$ & $\begin{array}{c}43.0 \\
1\end{array}$ & 4.6 & $\begin{array}{c}20.0 \\
6\end{array}$ & 11.4 & 10.4 \\
\hline 2 & $\begin{array}{c}\mathrm{NiC}_{15} \mathrm{H}_{16} \mathrm{~N}_{2} \mathrm{O}_{4} \\
\mathrm{~S}\end{array}$ & $\mathrm{Ni}-\mathrm{L}_{2}$ & $\begin{array}{c}\text { Dark } \\
\text { Yellow }\end{array}$ & $7.5-8.0$ & $>300^{\circ} \mathrm{C}$ & $\begin{array}{c}51.0 \\
8\end{array}$ & 4.5 & 7.3 & 18.1 & 8.3 \\
\hline
\end{tabular}

\section{Conductivity and Electronic Absorption Data of Ni (II) Complexes}

Table-3: Conductivity and Electronic Absorption Data of Ni (II) Complexes

\begin{tabular}{c|c|c|c|c|c}
\hline S. No. & $\begin{array}{c}\text { Compound } \\
\text { Code }\end{array}$ & $\begin{array}{c}\text { Molar } \\
\text { Conductance } \\
\Omega^{-1} \mathrm{~cm}^{2} \mathrm{~mol}^{-1}\end{array}$ & $\begin{array}{c}\text { Magnetic } \\
\text { Properties }\end{array}$ & & \multicolumn{2}{|c}{\begin{tabular}{c} 
Absorption Maxima $\mathrm{cm}^{-1}(\mathrm{~nm})$ \\
\cline { 4 - 5 }
\end{tabular}} & & & $\begin{array}{c}\mathrm{A}_{2} \mathrm{~g} \rightarrow{ }^{3} \mathrm{~T}_{2} \mathrm{~g}(\mathrm{~F}) \\
\text { Weak }\end{array}$ & $\begin{array}{c}\text { Charge Transfer } \\
\text { Strong }\end{array}$ \\
\hline 1 & Ni-L $\mathrm{L}_{1}$ & 34.3 & Diamagnetic & $440 \mathrm{~nm}(227000$ & $\begin{array}{c}280 \mathrm{~nm}(35714), \\
360 \mathrm{~nm}(27700)\end{array}$ \\
\hline 2 & $\mathrm{Ni}_{2} \mathrm{~L}_{2}$ & 29.2 & Diamagnetic & $560 \mathrm{~nm}(17,857)$ & $240 \mathrm{~nm}(41,666)$ \\
\hline
\end{tabular}
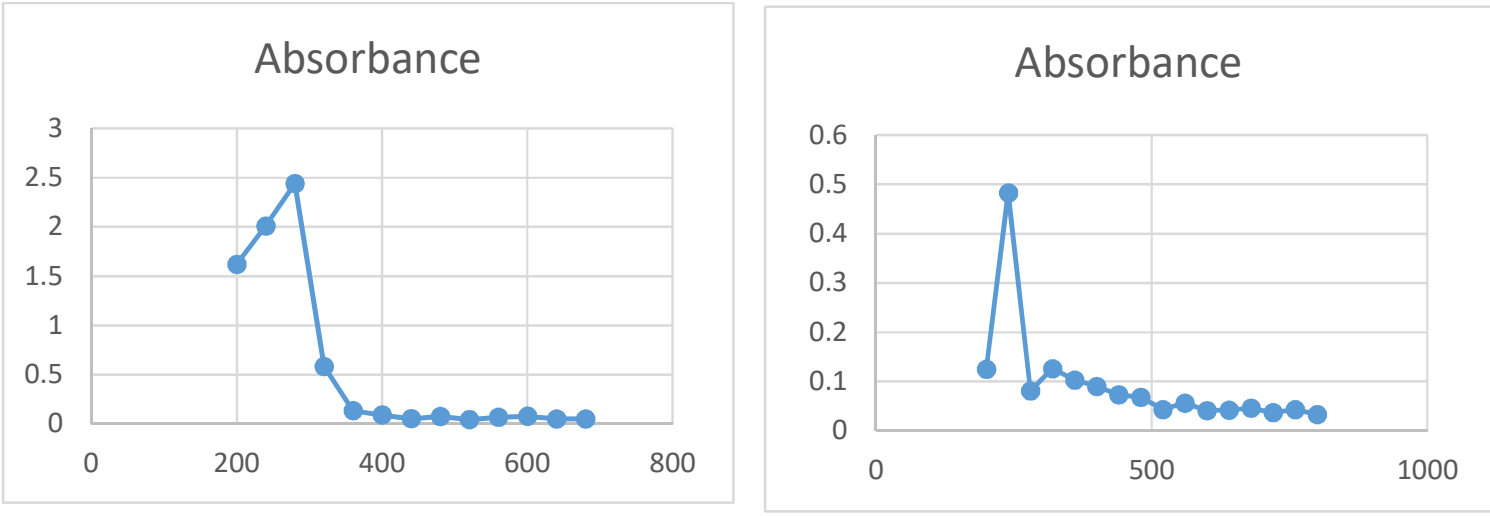

Fig.-6: Absorbance Vs. Wavelength Plot to obtain $\lambda_{\max }$ for Two Metal Complexes.

Octahedral Complexes generally consists of three bands in the range of 7000-13000 $\mathrm{cm}^{-1}, 10,000-20,000$ $\mathrm{cm}^{-1}, 19,000 \mathrm{~cm}^{-1}-27,000 \mathrm{~cm}^{-1}$. Whereas, square planar complexes show strong absorption bands in the range of 15,000 to $25,000 \mathrm{~cm}^{-1}$ and $25,000-35,000 \mathrm{~cm}^{-1}$ and also very low absorption band near 11,000 to $13,000 \mathrm{~cm}^{-1}$. Hence from the above data, it is revealed that complexes formed may have square planar structure. ${ }^{9,10}$

\section{Spectral Analysis of Metal Complexes \\ Infra-Red Spectral Data}

IR spectra of the above synthesized Schiff base ligand $L_{1}$ displays IR band around $1700 \mathrm{~cm}^{-1}$ which is assigned to the $-\mathrm{CH}=\mathrm{N}$ - group get shifted to $1698.83 \mathrm{~cm}^{-1}$, and band of $1744.10 \mathrm{~cm}^{-1}$ gets shifted to 1743.91 i.e. very marginally shifted towards lower side this confirms that azomethine donates its electrons to the $\mathrm{Ni}^{2+}$ forming metal complex. Also, a water molecule having broadband is observed around 3000 to $3500 \mathrm{~cm}^{-1}$. The same nature of IR is plotted for other Schiff base-metal complex $\mathrm{NiL}_{2}$. 
RASĀYAN J. Chem.

Vol. 13 | No. 1 | 282 - 290| January - March | 2020

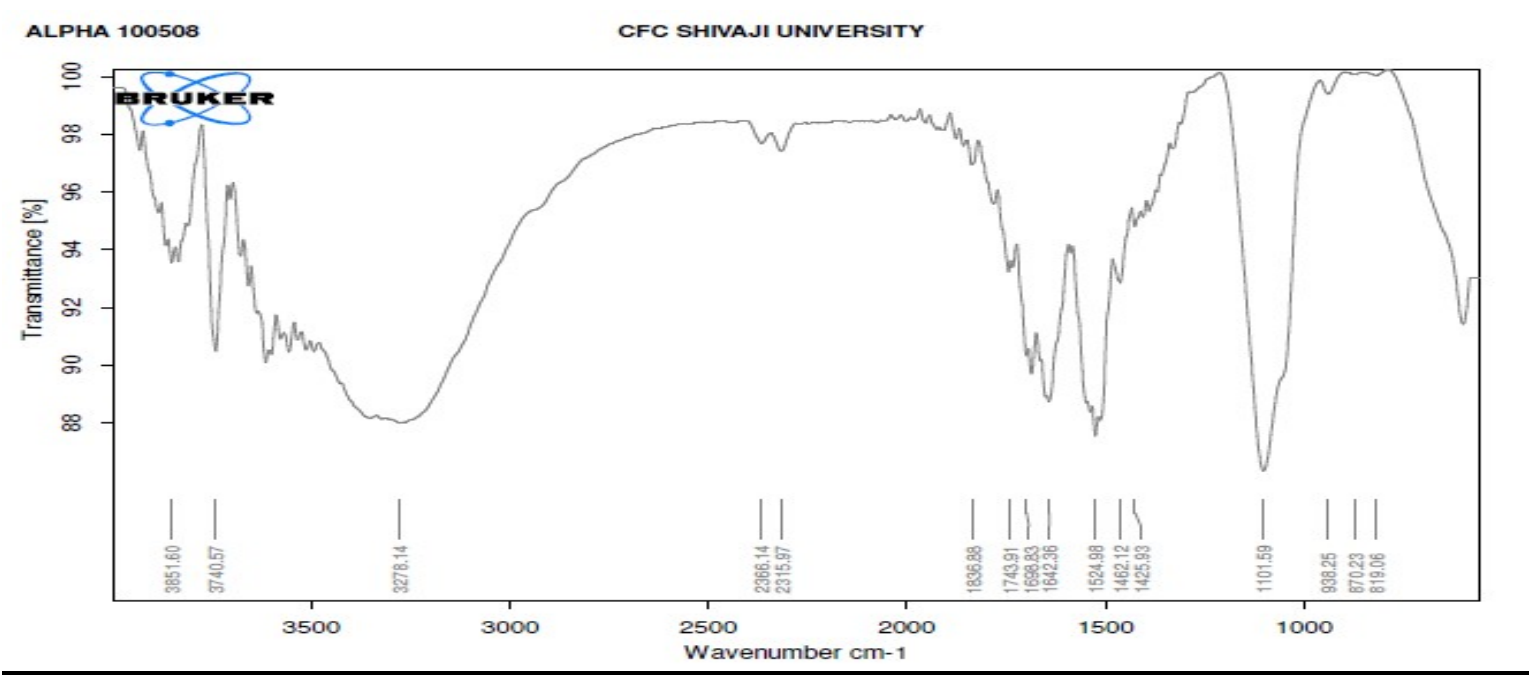

Fig.-6: IR Spectra of Schiff Base Metal Complexes NiL $\mathrm{N}_{1}$

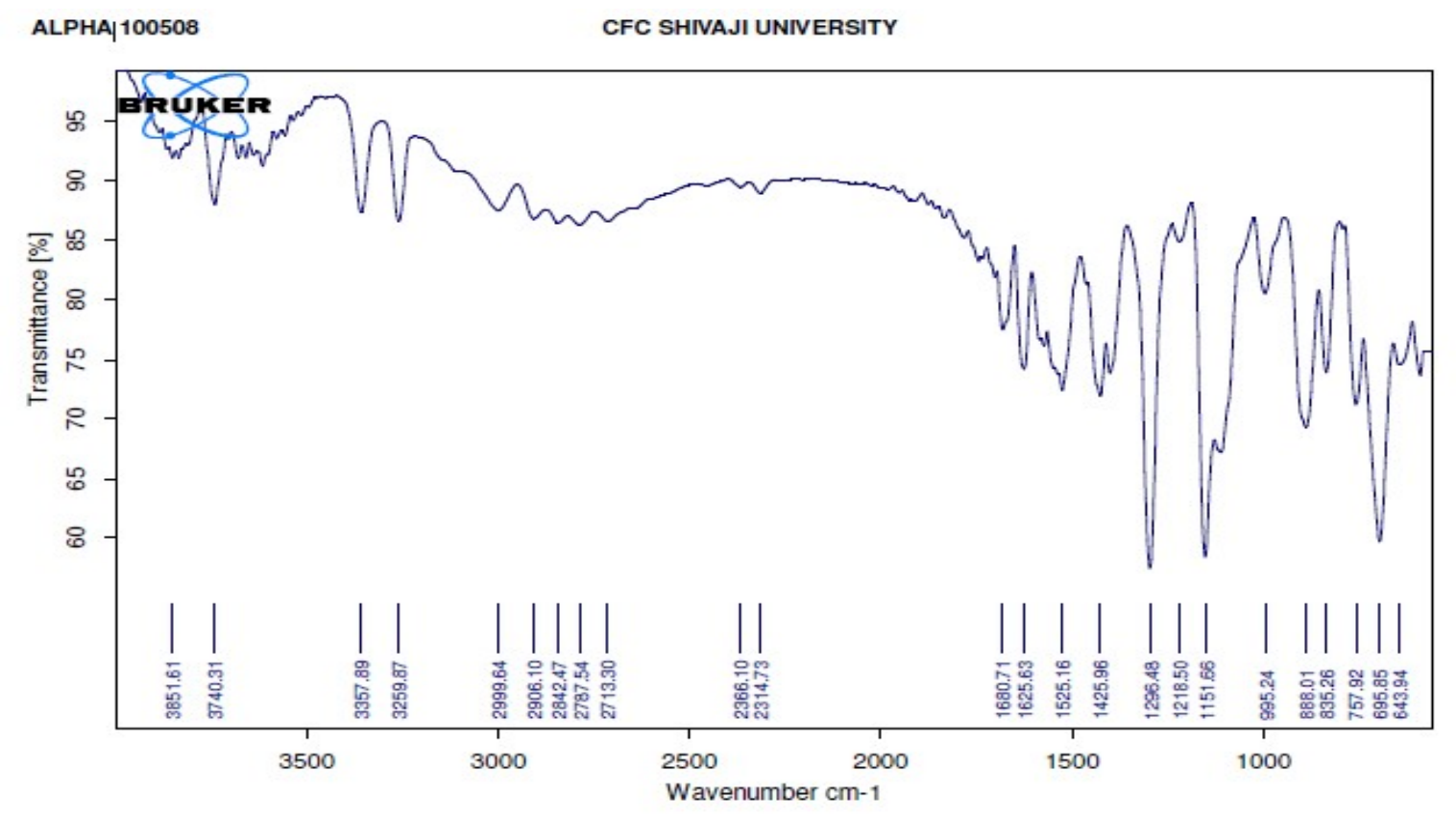

Fig.-7: IR Spectra of Schiff Base-Metal Complex $\mathrm{NiL}_{2}$

IR spectra of the Schiff base $\mathrm{L}_{2}$ shows IR band around $1685.69 \mathrm{~cm}^{-1}$ which is assigned to the azomethine group get shifted to $1680.71 \mathrm{~cm}^{-1}$, this confirms that azomethine donates its electrons to the $\mathrm{Ni}^{2+}$ forming metal complex. Hence, through all of the above data, we revealed that both the complexes have square planar geometry.

\section{Antibacterial Properties}

The Antimicrobial action was evaluated by the cup plate agar diffusion method by evaluating inhibition zones in millimeters. ${ }^{11,12}$ In-vitro antimicrobial activity of the prepared Nickel Complexes and that of the standard have been estimated against four following bacteria strains which include gram-positive bacteria like S. Aurious, S. Pyogen and gram-negative bacteria like E. Coli, P. Aeraginosa.

The results of antimicrobial action of the complexes indicate that the complexes show good antibacterial activity against gram-negative bacteria whereas it didn't show activity against gram-positive bacteria. 
RASĀYAN J. Chem.

Vol. 13 | No. 1 | 282 - 290| January - March | 2020

\section{Observations}

Hence, the above-reported compound has very good antibacterial action against gram-negative bacteria whereas it doesn't have any action counter to gram-positive bacteria indicating is specific and selective in nature.

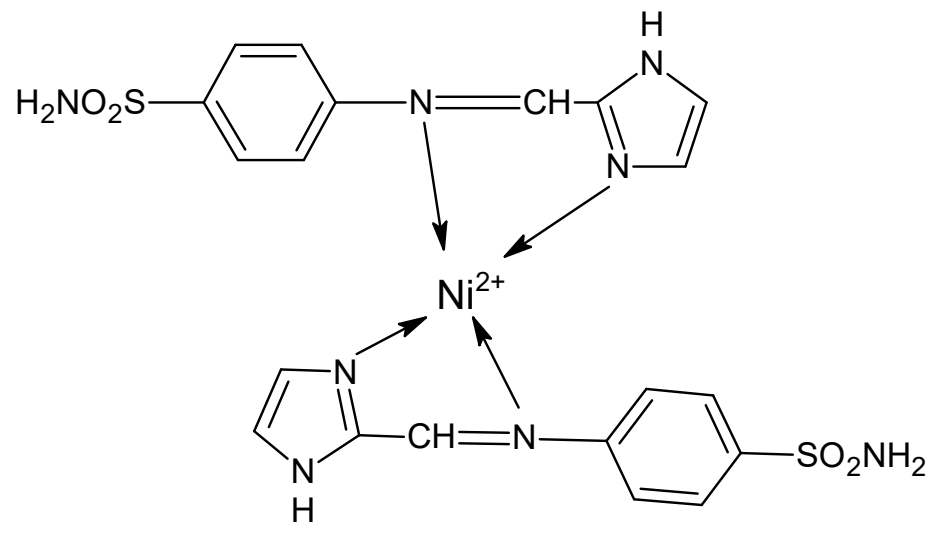

Scheme-3: Schiff base $\mathrm{L}_{1}$ Metal Complex

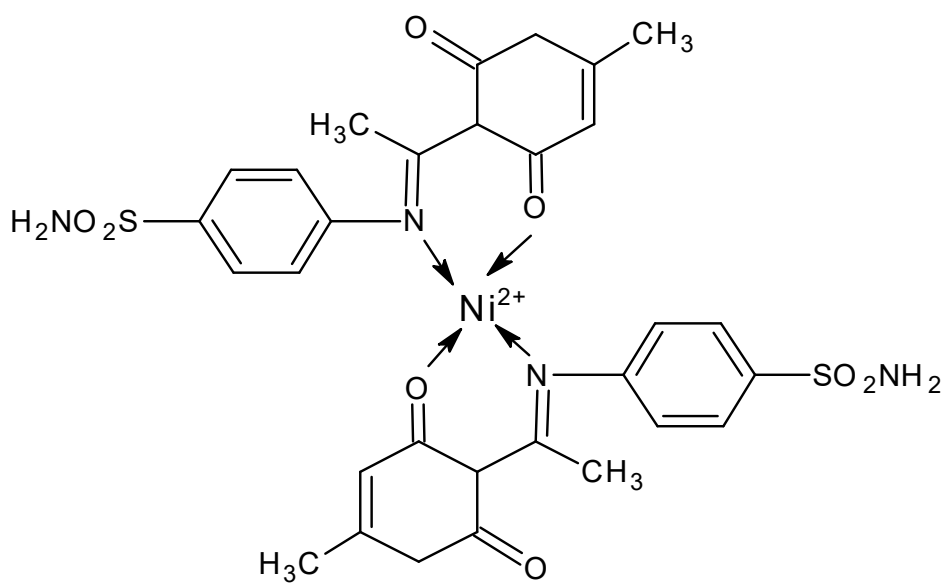

Scheme-4: Schiff base $\mathrm{L}_{2}$ Metal Complex

Table-4: Inhibition Values

\begin{tabular}{c|c|c}
\hline \multirow{2}{*}{ Bacterium } & \multicolumn{2}{|c}{ ZONE Inhibition $(\mathrm{mm})$} \\
\cline { 2 - 3 } & Complex NiL $_{1}(1000 \mathrm{ppm})$ & Complex NiL $(1000 \mathrm{ppm})$ \\
\hline E.Coli & 14 & 15 \\
\hline P.Aeraginosa & 14 & 16 \\
\hline S.Aurious & --------- & ------- \\
\hline S.Pyogen & -------- & --- \\
\hline
\end{tabular}

Nanoparticle Synthesis

Nickel oxide is also synthesized by the thermal decomposition method. ${ }^{13}$ The weighed quantity of abovesynthesized Nickel-metal complexes was taken into silica crucible. The silica crucible was kept in a muffle furnace. The furnace was then heated at $700^{\circ} \mathrm{C}$ for 3 hours in a normal atmosphere. The product obtained after thermal decomposition was naturally cooled to room temperature. The residue obtained in silica crucible was used for further characterization.

\section{Characterisation of SEM}

SEM image indicates that obtained product $\mathrm{NiO}$ nanoparticles are highly crystalline. The microgram looks to be gentle and shows rough morphology. The appearance of particles is in an irregular spherical 
RASĀYAN J. Chem.

Vol. 13 | No. 1 |282 - 290| January - March | 2020

shape. The particles are highly agglomerated and they are essentially clusters of nanoparticles. The observation of some larger nanoparticles may be due to its high surface energy and high surface tension. So we conclude that prepared $\mathrm{NiO}$ particles are in the Nano-meter range. The average diameter of the particles observed in 94 to $99 \mathrm{~nm}$.

Nickel oxide is an important metal oxide with many uses, such as it is the vital foundation for several high-critical temperature superconductors and resources with giant magneto resistance, and is also used as pigments in dyes, catalysts in many organic reactions, semiconductor, solar cells, gas sensors, cathode materials and magnetic loading media. ${ }^{14}$

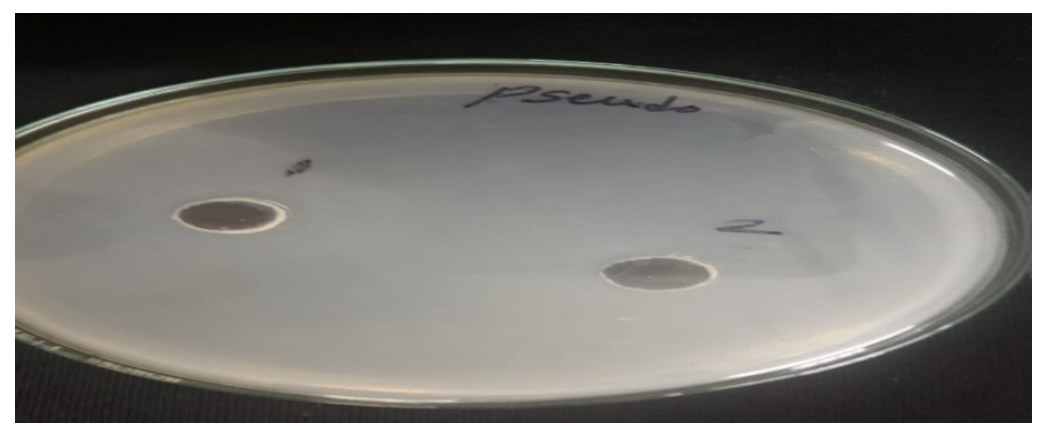

Fig.-1: Cup Plate Method Determining Activity against P.Aeraginosa

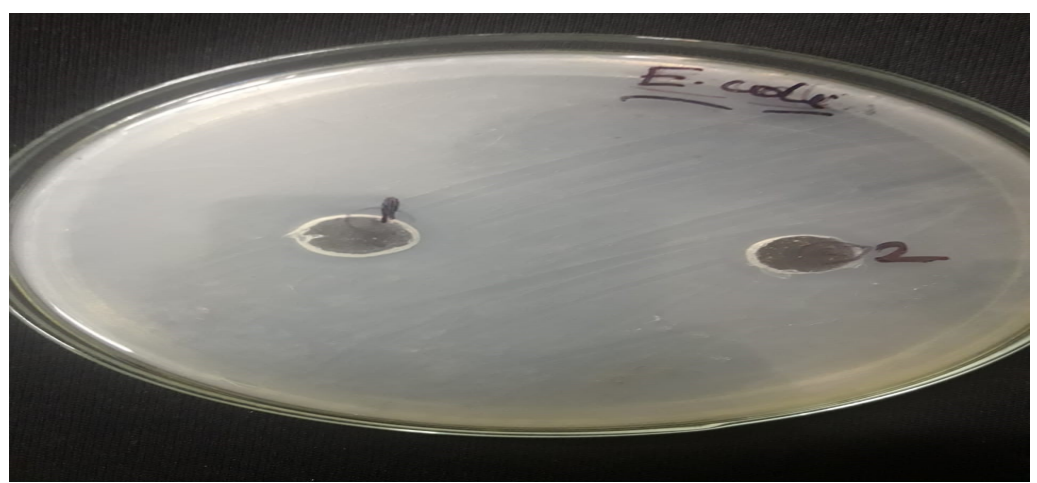

Fig.-2: Cup Plate Method Determining Activity Against E. Coli.

\section{CONCLUSION}

The composition of these Metal ligand complexes can be confirmed by the Slope ratio method, mole ratio method and jobs method of continuous variation ${ }^{15,16}$. All the results as mentioned above with the help of IR, Mass, NMR, UV-Vis spectra also reveals that the two prepared Nickel complexes have proposed 1:2 metal to ligand stoichiometry with square planar geometry. The estimated antimicrobial activity suggests that the complexes are having good antibacterial activity against gram-negative bacteria and hence may assist as means of transportation for initiation of the ligand as standard cytotoxic compounds. Also, the synthesized $\mathrm{NiO}$ Nanoparticles have good size in the range of $95 \mathrm{~nm}$ which can have a wide variety of applications and its further study needs to be revealed as it has application in the field of semiconductor, solar cells, storage media and pharmacy and cathode materials.

\section{ACKNOWLEDGMENT}

The corresponding author is thankful to the University of Mumbai for sanctioning the grant to this research project.

\section{REFERENCES}

1. S. Kousar, Lambert Academic Publishing (2015), Chemistry 68, (2015).

2. A. R. Ibrahim, International Journal of Advanced Research, 3(8), 315(2015).

3. Nabil Ramadan Bader, Rasayan Journal of Chemistry, 3(4), 660(2010). 
RASĀYAN $J$. Chem.

Vol. 13 | No. 1 | 282 - 290| January - March | 2020

4. Kamble Ganesh Joshi, Sunil Kokare, Arjun Zanje, Sunil Kolekar, Sanjay Ghule, Anil Gaikwad, Shashikant Anuse, Mansing, Separation Science and Technology, 52, (2016), DOI: 10.1080/01496395.2016.1255229

5. R. M. Patil and N. V. Thakkar, Synthesis and Reactivity in Inorganic and Metal-Organic Chemistry, 30(6), 1159(2000).

6. M. Montazerozohori, S.Joohari, V. Nouroozi, S.Hashemi, Z. Kazemi, S. Musavi, Indian Journal of Science and Technology, 4(4), 373(2011).

7. Suraj B. Ade, M.N. Deshpande and J.H. Deshmukh, Rasayan Journal of Chemistry, 5(1), 10(2012).

8. B. M. Kalshetty, R. S. Gani, S.S.Karabasannavar and M.B.Kalashetti, Global Journal of Science Frontier Research Chemistry, 13(2), 28(2013).

9. F. Cotton, G. Wilkinson, Advanced Inorganic Chemistry, Wiley Eastern, 896(1990).

10. Seema I. Habib and Praffullakumar A. Kulkarni, International Journal of Advances in Pharmacy, Biology and Chemistry, 1(2), 234(2012).

11. Ramachandra Akkasali, Nirdosh Patil and S. D. Angadi, Rasayan Journal of Chemistry, 2(1), 81(2009).

12. S.Pattanaik, S.S.Rout, J.Panda, P.K.Sahu and M Banerjee, Rasayan Journal of Chemistry, 4(1), 136(2011).

13. M.E. Mhadaye, Ph. D. Thesis, Department of Chemistry, University of Mumbai, Mumbai, Maharashtra, India (2017).

14. L. A. Saghatforoush, S. Sanati, Gh. Marandi M. Hasanzadeh, Journal of Nanostructures, 3, 33(2013), DOI: 10.7508/jns.2013.ournal of01.005

15. A. B. Shaikh, U. B. Barache, T. N. Lokhande1, G. S. Kamble, M. A. Anuse and S. H. Gaikwad, Rasayan Journal of Chemistry, 10(3), 967(2017), DOI:10.7324/RJC.2017.1031804

16. Ganesh S. Kamble, Ashwini P. Gaikwad, Balasaheb N. Kokare, Sanjay S. Kolekar, Sung.

17. H. Han, Mansing A. Anuse, Industrial \& Engineering Chemistry Research, 50(19), (2011), DOI: $10.1021 / \mathrm{ie} 200812 \mathrm{~W}$

[RJC-5532/2019] 